\title{
ACADEMIC EXPERIENCE OF THAI INTERNATIONAL UNDERGRADUATE STUDENTS AT UNVERSITAS MUHAMMADIYAH SURAKARTA
}

\author{
Fitri Kurniawan, Fina Azulfa \\ Universitas Muhammadiyah Surakarta \\ Email: fitri.kurniawan@ums.ac.id,finaazulfa@gmail.com
}

\section{Introduction}

Indonesia is one of the biggest destination countries for neighbouring international students to pursue their higher education. The statistics shows at least 3,000 international students study in Indonesia, pursuing their degree in universities (Jakarta Post 2014). This figures includes three big neighbouring countries respectively; Malaysia, Thailand and Vietnam (ibid). Thai students are significantly thriving in number as universities in Indonesia are favoured in terms of culture similarity (Ummu, 2019). Correspondingly, Indonesia has been the second destination country for southern Thailand studentsto study in higher education after EgyptSouthern Border Provinces Administrative Center(SBPAC, 2018). Not to mention, the scholarship schemes offered by Indonesian government for Thai international students are increased continuously.

This leads to a rapid increase of Thai students who enroll in universities in Indonesia.

Additionally, a number of scholarships offered by Indonesian government annually boost the number of Thai students in Indonesia. While studying in new countries can be best prize for the Thai international students, academics dynamic can be challenging (IIE, 2018).

Thai students are encouraged to pursue the degree abroad by the number of available scholarship and funding. Thai students have large opportunity to get the degree abroad on the platform of government scholarship and self-funded scheme. A common scholarship would coverfull scholarship with responsibility on returning to Thailand to work in Thailand office of the corporate entity granting the scholarship(SBPAC, 2018). Hence, the number of Thai international students is growing over time. However, this increase is not without a problem, number of cases reported Thai international students struggle with their academics due to a various adversities they face in the new country where they study. For this reason, understanding the nature of the academic experiences of Thai international is worth to investigate. This can shed a better understanding of their experiences. To encourage successful learning, the international students voice and in educational policy are necessary (Zhao et al., 2005).

\section{Research Method}

While many studies have discussed about Thai International students abroad, few specifically research which focus on the academic experience of Thai international students in Indonesia and most investigate Thai international students in UK, Germany and Egypt rather than in Indonesia specifically. Moreover, very few research which focus on the academic experience of Thai international students. The current research focuses on the subjective experience of the Thai international students who undergo the study or academic experience in Universitas Muhammadiyah Surakarta. Therefore, the research requires the approach that can accommodate the perception from the participants who involve in the phenomena. Accordingly, this research employs Hermeneutic phenomenology as an appropriate methodology which was adopted fromMax van Manen's work (1997).

Hermeneutic phenomenology is a research methodology designed for producing rich 
textual descriptions of the experiencelife of individuals on phenomena that are able to relate to the experience of all of us collectivelyJones (1975). The research methodology is selected depends on the research questions and the philosophical perspective from which the questions are to be investigated Kvale (1996). Theresearch is designed to understand the nature of the phenomenon of academic experience on Thai international student at Universitas Muhammadiyah Surakarta. However, the main focus of phenomenology is experiences and feelings as the core of the phenomenon, and a key aspect of this research is investigatingThai international students' academic experience studying at Universitas Muhammadiyah Surakarta. The use of hermeneutic phenomenology allowsstudy of participants' experiences with further construct and understanding by the researchers based on researcher's theoretical and personal knowledgeBogdan(1998). The Communication and language are interweaved and hermeneutics phenomenology compromises a way of understanding human experiences captured through language and in context (van Manen, 1997).

This method selected for this study to explore the Thai undergraduate internationalstudents'experiences at English Department, Universitas Muhammadiyah Surakarta. This study start with the research questions; "How do Thai undergraduate international studentsconstitute their academic experiences at Universitas Muhammadiyah Surakarta.

The focus of this research is the exploration ofThai international students' academic experiences at Universitas Muhammadiyah Surakarta. Therefore, theresearch searches for a design which is appropriate to explore the academic experiences of the participants. Hermeneutic phenomenology is selected for its focus is the experiences of the participant. There are somedesigns that may apply and match the aim of the research. They are grounded theory Glasser (2007) and narrative (Riesman, 2008). Nevertheless these were not selected in favor of phenomenological research.The grounded theory is a research design which aims at generating a theory Glasser,(2007). While grounded theory aims at generating theory while the objective of this research is not at creating theory. The research aims to understand the phenomenon being explored. Therefore, the grounded approach was not selected.Hence, a hermeneutic phenomenological research is chosen to explain a phenomenon through participants'experiences (Van Manen, 1997).In hermeneutic phenomenology, participants(s) Thai undergraduate international students and researcher co-construct the meaning of the experiences being investigated to analyse the perception.

\section{Result and Discussion}

Having analyzed the data through a series of member checking, the finding suggests two key points of Thai international perception on their academic experience at Universitas Muhammadiyah Surakarta. The findings are limited by the context and scope, therefore is not to be generalized. Nevertheless, it may give a better understanding on the nature of Thai international students' academic experience at Universitas Muhammadiyah Surakarta.

1. While Thai students can integrate with individual task given by lecturer, problems found inthe team class work project or group assignment given by lecturer.

2. Bilingual class; English and Bahasa Indonesia class help Thai students to understand the teaching material better.

\section{Discussion}

At the first stage of data analysis, a raw transcript was interpreted through member checking; the process where data interpreted through a constructive discussion among between researcher and supervisor. The interpretation was conducted in at least three phases.

The first interpretation by the researcher results explicative initial themes. At second 
phase, the themes discussed with others researchers include the research supervisor. At this stage, theme emerged were selected and reduced. At the last stage of member checking, the explicative data were given to the participant to have anotherlatter interpretation and confirmation on the themes agreed upon. The two explicative themes found in the data analysis are acquired through a prolonged and detail data driven based - discussion.

The first finding shows Thai international students can cope with individual task given in the class by the lecturer. This includes their ability to complete and accomplish the task given in relatively non problematic process as it can be understood in the following participant's transcript.

No problem with task and assignment in the class. Uhmm The lecturer makes it easy for us to finish the task, individual task. Yes, the task is easy for individual but not easy when it group homework. I don't like group project. It is not easy. Not easy to find a friends in the group or even to meet to complete the project. May be because all students are busy but it's not easy.

While individual task seems to be doable for Thai international students, they express and indicate a barrier in the group task or project in the class.

I always have problem to join the group project. My name is in the group but I only join the group in the class, only in the class presentation not in the process. I rarely make it to the meeting before class presentation. I think it's communication if they give me the day and time I have other class schedule if I'm free they have class

Similarly, there is a challenge met by Thai international students. It is not seems to be an available task for them to complete. They continuously complain aboutthe group project
I like the class, I like the lecturer I like it I enjoy my study but I just don't feel okay for group homework from lecturer there is a no time for me to meet the schedule with my friends why can't we just have individual task!

The participants repeatedly express the grievance on the group project or homework give by the lecturer

Group project is not good! (laugh) not good!

Not about the material, but it's; not uhm there is no time for group meeting ater class

Simply difficult, the academics schedule is already full for us

Nothing last, we can only meet in the class

The second explicative theme shows how the class in which some lecturers uses Bahasa Indonesia and English assist the Thai international students to understand the teaching material better. Thai international students who study in Universitas Muhammadiyah Surakarta can speak Malay and understand Bahasa Indonesia adequately. For this reason, the use of bilingual teaching allows them to comprehend the material given in the class easier. This is as constantly expressed by the participant.

The class is sometimes in English sometimes in Bahasa Indonesia. I understand Bahasa Indonesia better than English I think, but yes easy for me to follow the explanation in the class when the lecturer uses two languages as a means of classroom communication; Bahasa Indonesia and English.

The participants tend to perceive their Bahasa Indonesia is better than their English. Hence, they prefer the class whose lecturer uses bilingual language in the class room. 


\section{Conclusion}

In this study the researcher sets out to conclude the study with answer to the research questions. The purpose of this hermeneutic phenomenological research is to investigateacademic experience of Thai undergraduate international students at Universitas Muhammadiyah Surakarta. While the results from the study cannot be generalized, it helps answering the research question in the following ways.

The academic experiences of Thai undergraduate international students at Universitas Muhammadiyah Surakarta are constituted in two keytopics.

1. While Thai students can integrate with Indonesian students outside the class, problemsseem to be inthe team class work project or group assignment given by lecturer

2. The use of bilingual language; Bahasa Indonesia and English in the class by lecturers benefit Thai students to understand the teaching material better

Further study focuses on the academic experiences of different universities and department is recommended. However, the replication of the research can be done by expanding the number of participants to be investigated. These study ascent new questions for areas of future study of understanding theThai undergraduate international students at Universitas Muhammadiyah Surakarta in Indonesia.

\section{References}

Riessman, C.K. (2008). Narrative methods for the human sciences. London: Sage.

Bogdan, R. C., \& Biklen, S. K. (1998). Qualitative research for education: an introduction to theory and methods. Needham Heights, MA: Allyn \& Bacon

Church, A. T. (1982). Sojourner adjustment. Psychological Bulletin, 91(3), 540-572.

Glaser, B. (2007). Experts patsy and the subcon Transaction.

Jin, L. \& Cortazzi, M. (1998) The culture the learner brings: a bridge or a barrier? in: M. Byram\& M. Fleming (Eds) Language learning in intercultural perspective, approaches through drama and ethnography (Cambridge, Cambridge University Press), 98-118.

Jones, W. T. (1975). The Twentieth Century to Wittgenstein and Sarte (2nd revised ed.). San Francisco: Harcourt Brace Jovanovich.

Kvale, S. (1996). InterViews: An introduction to qualitative research. Thousand Oaks, CA: Sage.

Koch, T. (1996). Implementation of a hermeneutic inquiry in nursing: Philosophy, rigor and representation. Journal of Advanced Nursing, 24, 174-184.

Narjes, M. 2005, 'Adjustment problems of Iranian International students in Scotland', International educational journal, Vol. 484

Peterson 1999, D.M., BRIGGS, P., DREASHER, L., HORNER, D.D. AND NELSON, T. (1999) 'Contributions of international students and programs to campus diversity'. New Directions for Student Services 86: 67-77

Pelletier, C. (2003) The Experiences of International Students in Higher Education: a review of unpublished research: Report. [online] UKCOSA [accessed 27 June 2005]. Available from<HTUhttp://www.ukcosa.org.uk/images/ioereport.docUTH>

Polkinghorne, D. (1983). Methodology for the human sciences: Systems of inquiry. Albany: State University of New York Press. 
Ryan, J. (2000) A guide to teaching international students (Oxford, Oxford Centre for Staff \& Learning Development, Oxford Brookes University).

Spencer-Oatey, H. \& Xiong, Z. (2006) Chinese students' psychological and sociocultural adjustments to Britain: an empirical study, Language Culture and Curriculum, 19(1), $37-53$.

Ummu 2019, Phenomenological Study on Thai Undergraduate Students Lived Experience at Department of English Education Universitas Muhammadiyah Surakarta

van Manen, M. (1997). Researching lived experience: Human science for an action sensitive pedagogy (2nd Ed.). London, Canada: The Althouse Press.

Wisker, G. (Ed.) (2000) Good practice working with international students (Birmingham, SEDA). 76 M. Peelo and T. Luxon

Ward, C., \& Rana-Deuba, A. (2000). Home and host culture influences on sojourner adjustment. International Journal of Intercultural Relations, 24, 291-306.

Zhao 2005, C.M. , KUH, G.D. AND CARINI, R.M. (2005) 'A comparison of international students and American student engagement in effective educational practices'. Journal of Higher Education 76(2): 209-31.

http://www.umm.ac.id/id/muhammadiyah/14156.html

https://www.republika.co.id/berita/en/islam-in-archipelago/12/06/26/m68fqe-muhammadiyahgives-scholarships-to-71-students-from-south-thailand

https://www.thejakartapost.com/news/2014/01/11/high-time-internationalization-indonesianhigher-learning.html

https://en.antaranews.com/news/115938/southern-thai-students-prefer-to-study-in-indonesia

https://www.iie.org/Why-IIE/Announcements/2018/11/2018-11-13-Number-of-InternationalStudents-Reaches-New-High 